\title{
Developing Aesthetic Education Programme for Adults in Realization of Sustainable Development Goal Eleven (11) in Rivers State
}

\author{
Nwizu, Stella C. ${ }^{1}$ \& Olori, Christian N. ${ }^{1}$ \\ ${ }^{1}$ Department of Adult Education and Extra Mural Studies, University of Nigeria, Nsukka \\ Correspondence: Olori, Christian N., Department of Adult Education and Extra Mural Studies, University of Nigeria, \\ Nsukka, Nigeria. E-mail: christian.olori@unn.edu.ng
}

Received: Maech 30, 2020 Accepted: April 21, $2020 \quad$ Online Published: April 30, 2020

doi:10.5539/res.v12n2p33

URL: https://doi.org/10.5539/res.v12n2p33

\begin{abstract}
The rise in population explosion characterized by influx of activities of multinational oil companies in Rivers State has called for the need to make cities and human settlements inclusive, safe, resilient and sustainable (SDG 11). This study therefore aimed at developing aesthetic education programme for adults in realization of sustainable development goal 11 in Rivers State, Nigeria. The study was guided by four objectives. The research and development design was adopted for the study. The population of the study was 2,022 respondents made up of 170 facilitators and 1,653 learners from the three senatorial districts in the state. The proportionate stratified random sampling technique was used to select $30 \%$ of the population as the sample size. Instrument for data collection was the researchers' structured questionnaire which was face validated by three experts. Data collected were subjected to descriptive and inferential analysis in the statistical package for social sciences (SPSS) software version 21. Findings revealed that transmitting knowledge for disaster management and development of perceptual sensitivity on aesthetic experiences were some of the objectives of aesthetic education programme. The study further revealed disaster management and cultural norms and values as some of its contents. Brainstorming and observation were some of the delivery systems, while discussion and the use of video clips among others were evaluation strategies. Recommendations and implications were further provided.
\end{abstract}

Keywords: aesthetic, aesthetic education, sustainable development goal, adults, rivers state

\section{Introduction}

The development of an aesthetic education programme for adults in realization of sustainable development goal eleven (11) following the significant transformation in terms of human settlements is orchestrated by population explosion and the activities of multinationals in exploration and exploitation of crude oil products in Rivers State. Bolajoko (2004) remarked that the expansion of the world's population into niches and increasing human population has facilitated the transmission of diseases from person to person resulting in epidemiological changes. More so, on the activities of the multinationals, Ugbomeh (2008) stipulated that its high activity level in the Niger Delta has exposed the area to the dangers of pollution of water, land and air, as well as oil spills which have endangered aquatic life as well as the entire ecosystem, topography and surface vegetation.

Rivers State is one of the 36 states of Nigeria, created on May 1967 by the then Head of State, Major General Gowon. The state is very rich in culture and arts with some of the cultural bonds as music, dances and masquerades. The state has a population of 3,187,864 (Nigeria, 1991) and accounts for 3.58 percent of Nigeria's population. The state is also notable for tourist attractions, with long expanses of beautiful coastal sandy beaches stretching from Opobo through Brass to Koluama, together with numerous long and winding creeks, streams, rivers as well as forests with their associated shrines and wildlife. As a major theatre in the slave traffic and palm oil trade in the mid nineteenth and early twentieth century, Rivers State is endowed with war relics, artefacts and historical monuments. This invariably accounts for its rich cultural heritage.

The obvious destruction of lives and property with the rich cultural endowment in Rivers State caused by the activities of the multinational oil companies and the need to rejuvenate the region underscores the importance of adult education. This is because adult education is an organized learning activity directed at equipping the adults with new skills and competencies to fit into the changing world of work (Olori, 2019). In addition to this prospect, the Federal Republic of Nigeria (2014) stipulated the provision of aesthetic, cultural and civil education to adult citizens of the country for public enlightenment as the fifth goal of Mass Literacy, Adult and Non-formal education.

Aesthetic education is concerned with the edification of the surrounding through art to promote healthy and habitable 
environment. Promoting habitable environment may not be farfetched in that education is a sure pathway to liberation of man and the improvement of socio-economic status of the people (Sule, 2004). Aesthetic education therefore equips the adults with the knowledge and skills for perceiving, interpreting, internalizing and creating aesthetic values that is manifested in different situations (art, nature, human behaviour and the community). This education is the capacity to perceive, respond and be sensitive to natural environment and to human creation. Reimer (1998) averred that introducing the adults to art, undergoing aesthetic experience and not just acquiring knowledge of art was conceived as the ultimate goal of aesthetic education. Aesthetic experience involves a holistic vision of increasing one's personal experience and artistic experiences from the past. It is this experience that brings about a therapeutic role of maintaining, strengthening and re-discovering of taste of life.

In addition to the above function, Ruiz (2004) submitted that aesthetic education can contribute to the acquisition of social competencies such as tolerance, interaction, cooperation, conflict-resolution, and citizenship. This education further plays a role in the construction of cultural identity and of a common culture, as well as openness to diversity to other cultures, and to inter-cultural dialogue. Suffice it to say that aesthetic education is an enterprise with great value for building cross-cultural understanding, while building a harmonious co-existence of different artistic and cultural backgrounds and knowledge. Thus, described as a weapon in the fight against poverty and exclusion, and the promotion of creative freedom and democracy (UNESCO, 2003).

Acquiring aesthetic education therefore will not only provide the adults with the knowledge of appreciation of arts and culture but promotion of natural heritage, values and norms. Art in this instance is a distinct body of theoretical knowledge, while art education is concerned with how to think about, appreciate and consume art. More so, the accessibility of aesthetic education will further promote the sustainability of cities, and human settlements. This is possible where a roadmap of the programme is provided for different categories of people. Invariably, this could be achieved with the development of aesthetic education programme. This is the notion behind the development of aesthetic education programme for adults in realization of SDG 11 which is making safe and resilient our cities and human settlements inclusive and sustainable. To this end, Greene (2001) saw this kind of education as integral to the development of persons to their cognitive, perceptual, emotional and imaginative development.

The goal eleven of the SDGs is not limited to making cities and human settlements inclusive, safe, resilient and sustainable, but targeted at ensuring access for all to adequate, safe and affordable housing and basic services and upgrade slums by 2030 (United Nations (UN),2015). This goal is also targeted at strengthening efforts to protect and safeguard the world's cultural and natural heritage. By safeguarding the environment and its settlement, it could be said that there is a direct relationship between attaining sustaining development goal eleven and aesthetic education.

Interestingly, various scholars have written extensively on the importance of aesthetic education in the society (Denac, 2014; Cuco, 2014 and Riuz, 2004). These studies have not been able to establish the need for the development of aesthetic education programme following the continuous deterioration of Rivers State in recent times. The proliferation of atmospheric pollution, and air borne diseases which are manifested in various forms have obviously defaced Rivers State, which was originally known as centre for tourists' attraction. Concerned over this deplorable state in terms of emission of toxics which are most likely to reduce life span of the inhabitants, the development of aesthetic education programme for adults realization of SDG 11 becomes a need. Ruiz (2004) rightly stated that the positive effects of aesthetic education are evident in the areas of social cohesion, community image/regeneration, health and well-being as well as education and learning.

The development of a programme entails bringing to reality an abstract in a logical manner. This is because programmes are essentially planned activities to be carried out or executed (Olaitan \& Ndomi, 2000). Thus, the development of aesthetic education programme is the composition of its objectives, contents, delivery systems and evaluation strategies. The objectives denote what the learners are expected to know, do, create or feel after undergoing the learning process (Burbank \& Pett, 2007). Contents on the other hand, is the knowledge, skills, attitudes and values to be learned (Osinem, 2008). The contents are further split into topics, facilitator's activities, and learners' activities. Having identified the topics, the delivery system sets in. This system has been subjected to different nomenclature such as instructional methods, instructional techniques, or delivery strategies. Kizlik (2016) stated that regardless of what it may be called, they are primarily descriptions of the learning objective-oriented activities and flow of information between facilitators and learners. The last phase which is the evaluation strategies is characterized by appraising the learner in line with stipulated objectives. This strategy determines whether a programme has achieved its stated objectives and measured the appropriateness of a given programme approach (Ogwo, 2015).

Given that the above processes are required for the development of aesthetic education programme, two key players are also needed for its efficacy. These are the facilitators and learners. According to Hogan (2005), facilitators are individuals with various skills and knowledge of people, process, technical, and experience to help a group reach the 
learning targets and objectives. This implies that they serve as advisers since their main focus is on the learning process rather than the learning content. It also presupposes that facilitators are likely to have the knowledge of the curriculum and the basic concepts needed in teaching adults on aesthetic education. Learners on the other hand are adults who occupy strategic place in the society by the roles they perform. Enrolling into flexible programme offered by adult education is conceived as an avenue to improve themselves or remedy some deficiencies that mar their participation in the larger society. This invariably informs the preliminary investigation to ascertain their needs and incorporate them in the development of the programme. Consequently, involving the facilitators and learners in the development of aesthetic education programme is a novelty in the field of adult education especially in the realization of sustainable development goal 11 in Rivers State. Hence, the thrust of the study.

\subsection{Objectives of the Study}

The aim of this study was to develop an aesthetic education programme for adults in realisation of sustainable development goal eleven (11) in Rivers State. The objectives of the study are specifically to:

i. determine the objectives of aesthetic education programme for adults in realization of SDG 11 in Rivers State.

ii. ascertain the contents of aesthetic education programme for adults in realization of SDG 11 in Rivers State.

iii. ascertain the delivery systems of aesthetic education programme for adults in realization of SDG 11 in Rivers State.

iv. determine the evaluation strategies of aesthetic education programme for adults in realization of SDG 11 in Rivers State.

\subsection{Formulation of Hypotheses}

The hypotheses are stated in null form and tested at .05 level of significance.

$\mathrm{H}_{\mathrm{o} 1}$ There is no significant difference between the mean ratings of facilitators and learners on the objectives of aesthetic education programme for adults in realization of SDG 11 in Rivers State.

$\mathrm{H}_{02}$ There is no significant difference between the mean ratings of facilitators and learners on the contents of aesthetic education programme for adults in realization of SDG 11 in Rivers State.

$\mathrm{H}_{03}$ There is no significant difference between the mean ratings of facilitators and learners on the delivery systems of aesthetic education programme for adults in realization of SDG 11 in Rivers State.

$\mathrm{H}_{04}$ There is no significant difference between the mean ratings of facilitators and learners on the evaluation strategies of aesthetic education programme for adults in realization of SDG 11 in Rivers State.

\section{Theoretical Framework}

The study was based on transformation learning theory propounded by J. Mezirow in 1991. Mezirow sees this theory as a process as well as an outcome of adult development. As a process, Mezirow submitted that meaning is made continually more clarified, though may not follow clearly defined steps or stages. In terms of outcome, Mezirow noted that development is an outcome of transformative learning. The theory provides a model of adult learning by explaining the process of how personal paradigms evolve and expand in adulthood. The theory explained how expectations, framed within cultural assumptions and presupposition directly influence the meaning derived from experiences. Thus, to transform is to create something new that has never existed before and could not be predicted from the past.

Transformation therefore is the creation and change of whole new form, function or structure. It is based on learning a system of profound knowledge or taking actions based on leading with knowledge and courage. The theory constitutes a comprehensive and universal model of the generic structures, elements and processes of adult learning. This is anchored on the assumption of constructivism, which holds that the way learners interpret their sense experience is central to making meaning and hence, learning. Thus, the goal of adult education is to help the adult become a more autonomous thinker by learning to negotiate his or her own values, meanings and purpose rather than uncritically acting on those of others. It also presupposes that the development of aesthetic education as a programme in adult education will obviously help in the provision of framework on which the teaching-learning of aesthetic education will be anchored. In addition, provide a sense of direction on topical issues capable of promoting and appreciating natural and cultural heritage. The relevance of this theory to the study is that with the discovery of new ideas for improving the surrounding by adults through art, a better way of managing the environment in order to be productive will be achieved.

\subsection{Review of Related Empirical Studies}

Cole (1985) investigated the effect of an aesthetic education programme on the development of aesthetic judgemnet of four six and eight-year-old children. The study employed the inquiry form about the programme as data collecting instrument. The result showed an increased aesthetic awareness of children. 
Adu-Agyem and Enti (2009) conducted a study titled 'learning: The role of aesthetics in education. The study adopted historical, descriptive and case study methods. Data were gathered through interview and observation. Analysis was done through the use of documentary. Findings showed that some activities that could or should be incorporated in the teaching of children to boost creativity were advocated.

Acer and Omeroolu (2008) determined the effect of aesthetic education on the development of aesthetic judgement six year old children. The study adopted the experimental design. Findings revealed that there was significant difference in the aesthetic judgement of male children in the experiment group who received aesthetic education. Further findings showed that educational and socio-economic level of parents did not have any effects on the aesthetic judgement of children.

Khayankij (2017) carried out a study on using the contemplative teaching method to enhance the awareness of the aesthetic experience of second year students majoring in early childhood. The study adopted the BABA approach as the design. Findings revealed that students mean score of aesthetic experience awareness and their mean scores of aesthetic experience concepts were higher with a statistical significance of .01 . The study also indicated that students consented that there were three learning outcomes-attitude towards young children, attitude toward themselves, and attitude toward aesthetic experience.

Denaway (2013) conducted a study titled, 'inquiry based curriculum in a public school art room: Aesthetic education and Lincoln Centre Institute'. The objective of the study was to analyse the origin of aesthetic education and important philosophical views related to it. Secondary data from Lincoln Centre Institute and Maxine Greene as well as texts, theses and dissertation related to LCI, aesthetic education, educational philosophy and curricular unit planning used to gather data. The data were analysed qualitatively. Findings of the study revealed that aesthetic education was a kind of learning that is stimulated by the desire to explore, find out, or to search for something.

Mottagi and Nowrozi (2013) investigated aesthetic education requirements and its components in the educational system. The purpose of the study was to determine the need and components of aesthetic cognitive education to diverse learning opportunities. Secondary sources were used to obtain data for the study. The data collected were analysed qualitatively. Findings of the study among others revealed that aesthetic education was effective in three crucial areas-emotional health in private life, social contexts for learning and problem-solving experience and increased levels of social health and systematic understanding of social and moral values.

\subsection{Study Rationale}

Researches have been conducted on the importance and place of aesthetic education (Cole, 1985; Acer \& Omeroolu, 2008; Adu-Agyem \& Enti, 2009; Denaway, 2013; Mottagi \& Nowrozi, 2013). These studies were concerned with the contributions of aesthetic education to the development of children especially with regard to their appreciation of beauty through arts. None of these studies delved into using aesthetic education to improve aesthetic values of environment destroyed by human activities. Restricting the studies to children is believed to not have provided aesthetic responses of any kind (Feeney \& Moravcik, 1987). These studies failed to establish a synergy between aesthetic education and other features such as sustainable development goals. More so, none of these studies was able to develop aesthetic education programme for adults in meeting varying needs confronting them. These lapses have provided a gap which the present study addressed. The study therefore was set to develop aesthetic education programme for adults in realization of sustainable development goal 11 in Rivers State.

\section{Method}

The study adopted the research and development (R \& D) design. This design according to Gall, Gall \& Borg (2007) uses research findings to design new products or procedures followed by the application of research method to field- test, evaluate and refine the products and procedures until they meet specified criteria of effectiveness, quality or similar standards. The authors further propounded 10 steps in the use of this design. The choice of R \& D is based on Gall, Gall \& Borg's suggestion on the flexibility of steps in developing an educational package.

The area of the study was Rivers State. There are 23 local government areas with three senatorial districts. These senatorial zones are Rivers West, Rivers South-East and Rivers East. One local government area was chosen from each of the three senatorial districts namely Ogba Egbema Ndoni (Rivers West), Tai (Rivers South-East) and Port Harcourt (Rivers East).

The population of the study was 2,022 respondents made up of 170 facilitators of adult education programmes and 1,653 learners in the three senatorial districts. The source of information was from the Planning, Research and Statistics unit of Rivers State Agency for adult and mass literacy education (SAME), 2019. Breakdown of the population further shows that in Rivers West, there were 33 facilitators and 391 learners. In Rivers South-East, 85 facilitators and 837 learners, while in South East, 52 facilitators and 425 learners. The proportionate stratified random sampling was used to select $30 \%$ 
of the population in each senatorial district, resulting to 51 facilitators and 496 learners.

The instrument for data collection was the researchers' structured questionnaire titled 'Development of Aesthetic Education Programme for Realization of SDG 11' (DAEPRS). The instrument was developed after conducting a need assessment by the researchers to ascertain baseline data required for the development of aesthetic education programme for actualization of SDG 11 in Rivers State for the learners. The questionnaire had two parts, A and B. Part A provided the demographic data of the respondents, while part B elicited information regarding development of aesthetic education programme with respect to its objectives, contents, delivery systems and evaluation strategies for actualization of SDG 11 in Rivers State. This part was arranged in four clusters. Cluster A was the objectives with five items. Cluster B had 13 items addressing the contents, while Cluster C had 21 items on delivery systems. Evaluation strategies were on cluster D with seven items. The total items on this part was 46, structured on a four-point rating of strongly agree (4- points), agree (3-points), disagree (2-points) and strongly disagree (1-point).

The questionnaire was further subjected to face validation by two experts from Adult and Non-formal Education and Extra-mural Studies and one from Science Education (Measurement and Evaluation unit) all from the University of Port Harcourt, Rivers State. Items on the questionnaire were scrutinized in terms of relevance, clarity and appropriateness in meeting the standard for developing aesthetic education programme for the realization of SDG 11 in Rivers State.

The reliability of the instrument was established through a trial testing on administering the questionnaire to 25 respondents comprising 10 facilitators and 15 learners from five adult education centres in Uyo Local Government Area of Akwa Ibom State. The choice of this local government area is because they share similar features such as educational characteristics and tradition with those of the study area. The internal consistency of the instrument was determined using the Cronbach Alpha statistic. The coefficient values for the clusters (A- D) were .61, .89, .93, and .90, while the overall was given as .96 .

The administration of the instrument was done by the researchers with the aid of three research assistants who were briefed on the nature of the study, administration of the instruments and clarification of questions that may pose some difficulty to the respondents. Data collected from the respondents were analyzed using the mean and standard deviation to answer the research questions. The benchmark of 2.50 was used for decision making. This implies that mean score below 2.50 was regarded as disagree, while those of 2.50 and above were agree.

The t-test statistic was used to test the null hypotheses at .05 level of significance. Thus, where the probability value (pvalue) is less than .05 level of significance, the null hypothesis was rejected. This means that significant difference was found between the two groups. But, where the probability value (p-value) is greater than .05 level of significance, the null hypothesis was not rejected. This means that significant difference was not found between the two groups. These data were all computed using the Statistical Package for Social Science (SPSS) software version 21.

\section{Results}

Out of the 547 copies of the questionnaire administered, 536 representing $98 \%$ were correctly filled and used for the study, while 11 copies $(2 \%)$ were wrongly filled and was discarded for the study.

Table 1. Demographic characteristics of respondents by percentage

\begin{tabular}{lllll}
\hline S/N & Senatorial district & L.G.A & Facilitators\% & Learners \% \\
\hline 1 & Rivers West & Ogba Egbema Ndoni & $10(21.27)$ & $115(23.52 \%$ \\
2 & Rivers South-East & Tai & $23(48.94)$ & $248(50.72)$ \\
3 & Rivers East & Port-Harcourt & $14(29.79)$ & $126(25.76)$ \\
& Total & & $\mathbf{4 7}(\mathbf{1 0 0})$ & $\mathbf{4 8 9}(\mathbf{1 0 0})$ \\
\hline
\end{tabular}

Source: Field Survey, 2019

Table 1 showed that there were 10 facilitators representing $21.27 \%$ with 115 learners representing $23.52 \%$ in Rivers West senatorial district. The Table also had Rivers South-East as $23(48.94 \%)$ for facilitators and $248(50.72 \%)$ as learners, while Rivers East had 14 (29.79\%) for facilitators and $126(25.76 \%)$ as learners. The Table concluded that majority of the respondents were from the Rivers South East, while the least was Rivers West. 
Table 2. Mean Ratings of Respondent on objectives of Aesthetic Education programme for Adults in Realization of SDG 11 in Rivers State

\begin{tabular}{|c|c|c|c|c|c|c|c|c|}
\hline \multirow[t]{2}{*}{$\mathbf{S} / \mathbf{N}$} & \multirow[t]{2}{*}{ Item statements } & \multicolumn{2}{|c|}{$\begin{array}{l}\text { Facilitators } \\
\underline{n}=47\end{array}$} & \multicolumn{2}{|c|}{$\begin{array}{l}\text { Learners } \\
n=489\end{array}$} & \multirow[t]{2}{*}{ GM } & \multirow[t]{2}{*}{ GSD } & \multirow[t]{2}{*}{ Dec } \\
\hline & & $\bar{x}$ & $\mathrm{SD}_{1}$ & $\overline{x_{2}}$ & $\mathbf{S D}_{2}$ & & & \\
\hline 1. & $\begin{array}{l}\text { Transmit knowledge for disaster } \\
\text { management }\end{array}$ & 3.45 & .75 & 3.36 & .87 & 3.41 & .81 & Agree \\
\hline 2. & $\begin{array}{l}\text { Promote environmental safety } \\
\text { services for sustainable } \\
\text { communities }\end{array}$ & 3.23 & .89 & 3.35 & .82 & 3.29 & .86 & Agree \\
\hline 3. & $\begin{array}{l}\text { Acquire ornamental skills for } \\
\text { environmental adornment }\end{array}$ & 3.36 & .87 & 3.25 & .92 & 3.31 & .90 & Agree \\
\hline 4. & $\begin{array}{l}\text { Safeguard cultural norms and } \\
\text { values }\end{array}$ & 3.45 & .88 & 3.24 & .93 & 3.35 & .91 & Agree \\
\hline 5. & $\begin{array}{l}\text { Develop perceptual sensitivity on } \\
\text { aesthetic experience }\end{array}$ & 3.49 & .88 & 3.31 & .92 & 3.40 & .90 & Agree \\
\hline & Overall Mean & & & & & 3.35 & .88 & Agree \\
\hline
\end{tabular}

Source: Field Survey, 2019

Note $\overline{x_{1}}=$ Mean for facilitators, $\overline{x_{2}}=$ mean for learners, $S D_{1}=$ Standard deviation for facilitators, $S D_{2}=$ Standard deviation for learners, $G M=$ grand mean, $G S D=$ grand standard deviation, $D e c=$ Decision

Table 2 indicated that items 1-5 on objectives of aesthetic education programme for adults had mean scores of 3.41, 3.29. $3.31,3.35$ and 3.40 respectively above 2.50 benchmark, while the standard deviation ranged from .81 to .91 , which is an indication of closeness of mean scores of respondents. The overall mean of 3.35 therefore showed that the above five items were objectives of aesthetic education programme for adults in realization of sustainable development goals (SDG) eleven in Rivers State.

Table 3. Mean Ratings of Respondents on Contents of Aesthetic Education Programme for Adults in Realization of SDG II Rivers State

\begin{tabular}{|c|c|c|c|c|c|c|c|c|}
\hline \multirow[b]{2}{*}{$\mathbf{S} / \mathbf{N}$} & \multirow[b]{2}{*}{ Item } & \multicolumn{2}{|c|}{$\begin{array}{l}\text { Facilitators } \\
n=47\end{array}$} & \multicolumn{2}{|c|}{$\begin{array}{l}\text { Learners } \\
\mathrm{n}=489\end{array}$} & \multirow[t]{2}{*}{ GM } & \multirow[t]{2}{*}{ GSD } & \multirow[t]{2}{*}{ Dec } \\
\hline & & $x_{1}$ & $\mathbf{S D}_{1}$ & $x_{2}$ & $\mathbf{S D}_{2}$ & & & \\
\hline 1. & Cultural norms and values & 3.36 & .79 & 3.29 & .97 & 3.33 & .88 & Agree \\
\hline 2. & Environmental safety & 3.58 & .72 & 3.25 & .96 & 3.42 & .84 & Agree \\
\hline 3. & Disaster management & 3.58 & .72 & 3.37 & .80 & 3.48 & .76 & Agree \\
\hline 4. & Environmental art & 3.43 & .85 & 3.21 & .91 & 3.32 & .88 & Agree \\
\hline 5. & Hygiene & 3.64 & .61 & 3.27 & .95 & 3.46 & .78 & Agree \\
\hline 6. & Horticulture (ornamental planting) & 3.51 & .78 & 3.27 & .92 & 3.39 & .85 & Agree \\
\hline 7. & $\begin{array}{l}\text { Environmental beautification such } \\
\text { as creation of foot paths }\end{array}$ & 3.60 & .71 & 3.23 & .95 & 3.42 & .83 & Agree \\
\hline 8. & Recreational activities & 3.55 & .83 & 3.22 & 1.00 & 3.39 & .92 & Agree \\
\hline 9. & Architectural design & 3.43 & .83 & 3.16 & .99 & 3.30 & .91 & Agree \\
\hline 10. & Urbanization & 3.49 & .75 & 3.31 & .89 & 3.40 & .82 & Agree \\
\hline 11. & $\begin{array}{l}\text { Environmental beautification such } \\
\text { as street lightening }\end{array}$ & 3.55 & .58 & 3.27 & .93 & 3.41 & .74 & Agree \\
\hline 12. & $\begin{array}{l}\text { Environmental beautification such } \\
\text { as good road networks }\end{array}$ & 3.55 & .78 & 3.19 & .93 & 3.37 & .86 & Agree \\
\hline \multirow[t]{2}{*}{13} & $\begin{array}{l}\text { Environmental beautification such } \\
\text { as good drainage system }\end{array}$ & 3.51 & .75 & 3.26 & .93 & 3.39 & .84 & Agree \\
\hline & Overall mean & & & & & 3.39 & .84 & Agree \\
\hline
\end{tabular}

Source: Field Survey, 2019

Note $\overline{x_{1}}=$ Mean for facilitators, $\overline{x_{2}}=$ mean for learners, $S D_{1}=$ Standard deviation for facilitators, $S D_{2}=$ Standard deviation for learners, $G M=$ grand mean, $G S D=$ grand standard deviation, Dec $=$ Decision

Table 3 showed that items $1-13$ had mean scores of agree as 3.33, 3.42, 3.48, 3.32, 3.46, 3.39, 3.42, 3.39, 3.30, 3.40, $3.41,3.37$ and 3.39 with corresponding standard deviation as $.88, .84, .76, .88, .78, .85, .83, .92, .91, .82, .74, .86$ and .84. The Table also revealed the overall mean of 3.39 above the benchmark of 2.50 . This implied that the 13 items were contents of aesthetic education programme for adults in realization of SDG 11 in Rivers State. 
Table 4. Mean Ratings of Respondents on Delivery Systems of Aesthetic Education Programme for Adults in Realization of SDG 11 in Rivers State

\begin{tabular}{lllllllll}
\hline S/N & Item Statement & \multicolumn{2}{c}{$\begin{array}{c}\text { Facilitators } \\
\mathbf{n}=\mathbf{4 7}\end{array}$} & \multicolumn{2}{c}{$\begin{array}{c}\text { Learners } \\
\mathbf{n = 4 8 9}\end{array}$} & \multicolumn{1}{c}{ GM } & GSD & Dec \\
$\mathbf{S} / \mathbf{N}$ & & $\boldsymbol{x}_{1}$ & $\mathbf{S D}_{\mathbf{1}}$ & $x_{2}$ & $\mathbf{S D}_{\mathbf{2}}$ & & & \\
\hline 1 & Pictures & 3.47 & .80 & 3.29 & .87 & 3.38 & .84 & Agree \\
2 & Observation & 3.60 & .68 & 3.34 & .89 & 3.47 & .79 & Agree \\
3 & Modelling & 3.62 & .65 & 3.27 & .88 & 3.45 & .77 & Agree \\
4 & Discussion & 3.58 & .58 & 3.27 & .90 & 3.44 & .74 & Agree \\
5 & Problem-solving & 3.51 & .62 & 3.29 & .90 & 3.40 & .76 & Agree \\
6 & Interview & 3.58 & .62 & 3.28 & .91 & 3.43 & .77 & Agree \\
7 & Video clips & 3.64 & .64 & 3.13 & .97 & 3.39 & .81 & Agree \\
8 & Charts & 3.53 & .72 & 3.32 & .91 & 3.43 & .82 & Agree \\
9 & Projectors & 3.47 & .66 & 3.28 & .89 & 3.38 & .78 & Agree \\
10 & Lecture & 3.26 & .77 & 3.04 & 1.01 & 3.15 & .89 & Agree \\
11 & Sociometry & 3.53 & .62 & 3.23 & .94 & 3.38 & .78 & Agree \\
12 & Drilling & 3.40 & .77 & 3.22 & .94 & 3.31 & .86 & Agree \\
13 & Confrontation & 3.64 & .57 & 3.12 & 1.01 & 3.38 & .79 & Agree \\
14 & TV set & 3.53 & .62 & 3.25 & .93 & 3.39 & .80 & Agree \\
15 & Drama & 3.51 & .66 & 3.27 & .93 & 3.39 & .80 & Agree \\
16 & Brain storming & 3.60 & .68 & 3.32 & .89 & 3.46 & .79 & Agree \\
17 & Dramatization & 3.51 & .72 & 3.10 & .97 & 3.31 & .85 & Agree \\
18 & Simulation & 3.53 & .66 & 3.18 & 1.01 & 3.36 & .84 & Agree \\
19 & Field trip & 3.60 & .61 & 3.22 & .91 & 3.41 & .76 & Agree \\
20 & Blended learning & 3.58 & .65 & 3.18 & .95 & 3.38 & .80 & Agree \\
21 & Dancing & 3.47 & .75 & 3.25 & .89 & 3.36 & .82 & Agree \\
& Overall mean & & & & & $\mathbf{3 . 3 8}$ & $\mathbf{. 8 0}$ & Agree \\
\hline
\end{tabular}

Source: Field Survey, 2019

Note $\overline{x_{1}}=$ Mean for facilitators, $\overline{x_{2}}=$ Mean for learners, $\mathrm{SD}_{1}=$ Standard deviation for Facilitators, $\mathrm{SD}_{2}=$ Standard deviation for learners, $\mathrm{GM}=$ Grand mean, $\mathrm{GSD}=$ Grand standard deviation, $\mathrm{Dec}=$ Decision

Table 4 revealed that all the 21 items had their grand mean scores ranged from 3.15 to 3.47 above 2.50 benchmark for agree. The grand standard deviation also ranged from .74 to .89 , showing the closeness of responses in the mean of the respondents. The overall mean of 3.38 showed that the identified 21 items were delivery systems of aesthetic education programme for adults in realization of SDG II in Rivers State.

Table 5. Mean Ratings of Respondents on Evaluation Strategies of Aesthetic Education Programme for Adults in Realization of SDG II in Rivers State

\begin{tabular}{|c|c|c|c|c|c|c|c|c|}
\hline \multirow[t]{2}{*}{$\mathbf{S} / \mathbf{N}$} & \multirow[t]{2}{*}{ Item Statement } & \multicolumn{2}{|c|}{$\begin{array}{l}\text { Facilitators } \\
\mathbf{n}=47\end{array}$} & \multicolumn{2}{|c|}{$\begin{array}{l}\text { Learners } \\
n=489\end{array}$} & \multirow[t]{2}{*}{ GM } & \multirow[t]{2}{*}{ GSD } & \multirow[t]{2}{*}{ Dec } \\
\hline & & $x_{1}$ & $\mathrm{SD}_{1}$ & $x_{2}$ & $\mathrm{SD}_{2}$ & & & \\
\hline 1. & $\begin{array}{l}\text { Using dialogue to ascertain } \\
\text { aesthetic education topics }\end{array}$ & 3.51 & .78 & 3.19 & .92 & 3.35 & .85 & Agree \\
\hline 2. & $\begin{array}{l}\text { Using video lips to compare art } \\
\text { past and present in the society }\end{array}$ & 3.48 & .75 & 3.37 & .91 & 3.43 & .83 & Agree \\
\hline 3. & $\begin{array}{l}\text { Examining buildings in traditional } \\
\text { and modern architectural styles } \\
\text { using modeling. }\end{array}$ & 3.55 & .65 & 3.21 & .91 & 3.38 & .78 & Agree \\
\hline 4. & $\begin{array}{l}\text { Encouraging the creation of works } \\
\text { of art through charts }\end{array}$ & 3.49 & .72 & 3.11 & 1.02 & 3.30 & .87 & Agree \\
\hline 5. & $\begin{array}{l}\text { Developing artistic expression in } \\
\text { various groups through dancing }\end{array}$ & 3.34 & .87 & 3.05 & 1.01 & 3.20 & .94 & Agree \\
\hline 6. & $\begin{array}{l}\text { Discussing environmental safety } \\
\text { services through observation }\end{array}$ & 3.64 & .61 & 3.17 & .96 & 3.41 & .79 & Agree \\
\hline 7. & $\begin{array}{l}\text { Examining ways of managing } \\
\text { disaster in the environment through } \\
\text { problem solving }\end{array}$ & 3.64 & .61 & 3.26 & .93 & 3.45 & .77 & Agree \\
\hline & Overall mean & & & & & 3.36 & .83 & Agree \\
\hline
\end{tabular}

Source: Field Survey, 2019

Note $\overline{x_{1}}=$ Mean for facilitators, $\overline{x_{2}}=$ Mean for learners, $\mathrm{SD}_{1}=$ Standard Deviation for Facilitators, $\mathrm{SD}_{2}=$ Standard deviation for learners, $\mathrm{GM}=$ grand mean, $\mathrm{GSD}=$ grand standard deviation, $\mathrm{Dec}=$ Decision 
Table 5 showed that items 1-7 had mean scores of agree as 3.35, 3.43, 3.38, 3.30, 3.20, 3.41 and 3.45 above 2.50 benchmark. The Table further had the standard deviation as ranging from .77 to .94 . The overall mean of 3.36 revealed that the respondents agreed with the seven items on evaluation strategies of aesthetic education programme for adults in realization of SDG II in Rivers State.

Table 6. t-test of Difference Between the Mean Ratings of Facilitators and Learners on Objectives of Aesthetic Education Programme for Adults in Realization of SDG II in Rivers State

\begin{tabular}{|c|c|c|c|c|c|c|c|c|}
\hline \multirow[t]{2}{*}{$\mathbf{S} / \mathbf{N}$} & \multirow[t]{2}{*}{ Item statements } & \multicolumn{2}{|c|}{$\begin{array}{l}\text { Facilitators } \\
\underline{n}=47\end{array}$} & \multicolumn{2}{|c|}{$\begin{array}{l}\text { Learners } \\
\underline{N}=489\end{array}$} & \multirow[t]{2}{*}{$\mathbf{t}_{\mathrm{cal}}$} & \multirow[t]{2}{*}{$\mathbf{P}_{\text {value }}$} & \multirow[t]{2}{*}{ Dec } \\
\hline & & $x_{1}$ & $\mathrm{SD}_{1}$ & $x_{2}$ & $\mathrm{SD}_{2}$ & & & \\
\hline 1. & $\begin{array}{l}\text { Transmit knowledge for disaster } \\
\text { management }\end{array}$ & 3.45 & .75 & 3.36 & .87 & .68 & .50 & NS \\
\hline 2. & $\begin{array}{l}\text { Promote environmental safety } \\
\text { services for sustainable } \\
\text { communities }\end{array}$ & 3.23 & .89 & 3.35 & .82 & .83 & .41 & NS \\
\hline 3. & $\begin{array}{l}\text { Acquire ornamental skills for } \\
\text { environmental adornment }\end{array}$ & 3.36 & .87 & 3.25 & .92 & .84 & .40 & NS \\
\hline 4. & $\begin{array}{l}\text { Safeguard cultural norms and } \\
\text { values }\end{array}$ & 3.45 & .88 & 3.24 & .93 & 1.62 & .11 & NS \\
\hline 5. & $\begin{array}{l}\text { Develop perceptual sensitivity on } \\
\text { aesthetic experience }\end{array}$ & 3.49 & .88 & 3.31 & .92 & 1.34 & .18 & NS \\
\hline & Overall Mean & & & & & & .32 & NS \\
\hline
\end{tabular}

Table 6 showed that all the five items had their t-calculated values ranged from .68 to 1.62. Since the p-value (.32) is greater than .05 level of significance, the null hypothesis of no significant difference is hereby upheld. This implied that there is no significant difference between the mean ratings of facilitators and learners on the objectives of aesthetic education programme for adults in realization of SDG II in Rivers State.

Table 7. t-test of Difference Between the Mean Ratings of Facilitators and Learners on the Contents of Aesthetic Education, Programme for Adults in Realization of SDG II in Rivers State

\begin{tabular}{|c|c|c|c|c|c|c|c|c|}
\hline \multirow[t]{2}{*}{$\mathbf{S} / \mathbf{N}$} & \multirow[t]{2}{*}{ Item statements } & \multicolumn{2}{|c|}{$\begin{array}{l}\text { Facilitators } \\
\underline{\mathrm{n}}=\mathbf{4 7}\end{array}$} & \multicolumn{2}{|c|}{$\begin{array}{l}\text { Learners } \\
\underline{n}=489\end{array}$} & \multirow[t]{2}{*}{$\mathbf{t}_{\text {cal }}$} & \multirow[t]{2}{*}{$\mathbf{p}_{\text {value }}$} & \multirow[t]{2}{*}{ Dec } \\
\hline & & $x_{1}$ & $\mathrm{SD}_{1}$ & $x_{2}$ & $\mathbf{S D}_{2}$ & & & \\
\hline 1. & Cultural norms and values & 3.36 & .79 & 3.29 & .97 & .63 & .53 & NS \\
\hline 2. & Environmental safety & 3.58 & .72 & 3.25 & .96 & 2.40 & .02 & $\mathrm{~S}$ \\
\hline 3. & Disaster management & 3.58 & .72 & 3.37 & .80 & 1.67 & .10 & NS \\
\hline 4. & Environmental art & 3.43 & .85 & 3.21 & .91 & 1.62 & .11 & NS \\
\hline 5. & Hygiene & 3.64 & .61 & 3.27 & .95 & 2.71 & .08 & $S$ \\
\hline 6 & $\begin{array}{l}\text { Horticulture } \\
\text { planting) }\end{array}$ & 3.51 & .78 & 3.27 & .92 & 1.74 & .01 & NS \\
\hline 7 & $\begin{array}{l}\text { Environmental beautification } \\
\text { such as creation of foot paths }\end{array}$ & 3.60 & .71 & 3.23 & .95 & 2.66 & .02 & S \\
\hline 8 & Recreational facilities & 3.55 & .83 & 3.22 & 1.00 & 2.28 & .06 & $\mathrm{~S}$ \\
\hline 9 & Architectural design & 3.43 & .83 & 3.16 & .99 & 1.87 & .19 & NS \\
\hline 10 & Urbanization & 3.49 & .75 & 3.31 & .89 & 1.31 & .03 & NS \\
\hline 11 & $\begin{array}{l}\text { Environmental beautification } \\
\text { such as street lightening }\end{array}$ & 3.55 & .58 & 3.27 & .93 & 2.16 & .03 & S \\
\hline 12 & $\begin{array}{l}\text { Environmental beautification } \\
\text { such as good road networks }\end{array}$ & 3.55 & .78 & 3.19 & .93 & 2.63 & .01 & $\mathrm{~S}$ \\
\hline 13 & $\begin{array}{l}\text { Environmental beautification } \\
\text { such as good drainage system }\end{array}$ & 3.51 & .75 & 3.26 & .93 & .08 & .06 & NS \\
\hline & Overall mean & & & & & & .10 & NS \\
\hline
\end{tabular}

Table 7 showed that items 1, 3, 4, 6, 9, 10 and 13 had t-calculated values of .63, 1.67, 1.62, 1.74, 1.87, 1.31 and .08 with p-values greater than .05 level of significance. Thus, significant difference was not found in the items. However significant different was found in items $2,5,7,8,11$ and 12 whose t-cal values were 2.40, 2.71, 2.66, 2.16 and 2.63 with associated p-value less than .05 level of significance. With an overall p-value (.10) greater than .05 level of significance, the null hypothesis of no significance difference was upheld. This implied that there was no significant difference between the mean ratings of facilitators and learners on contents of aesthetic education programme for adults in realization of SDG 
11 in Rivers State.

Table 8. t-test of Difference Between the Mean Ratings of Facilitators and Learners on Delivery Systems of Aesthetic Education Programme for Adults on Realization of SDG II in Rivers State

\begin{tabular}{|c|c|c|c|c|c|c|c|c|}
\hline \multirow[t]{2}{*}{$\mathbf{S} / \mathbf{N}$} & \multirow[t]{2}{*}{ Item Statements } & \multicolumn{2}{|c|}{$\begin{array}{l}\text { Facilitators } \\
\mathrm{n}=47\end{array}$} & \multicolumn{2}{|c|}{$\begin{array}{l}\text { Learners } \\
n=489\end{array}$} & \multirow[t]{2}{*}{$\mathbf{t}_{\text {cal }}$} & \multirow[t]{2}{*}{$\mathbf{p}_{\text {value }}$} & \multirow[t]{2}{*}{ Dec } \\
\hline & & $x_{1}$ & $\mathrm{SD}_{1}$ & $x_{2}$ & $\mathbf{S D}_{2}$ & & & \\
\hline 1 & Pictures & 3.47 & .80 & 3.29 & .87 & .35 & .21 & $\mathrm{NS}$ \\
\hline 2 & Observation & 3.60 & .68 & 3.34 & .89 & .01 & .06 & NS \\
\hline 3 & Modelling & 3.62 & .65 & 3.27 & .88 & .01 & .01 & $\mathrm{~S}$ \\
\hline 4 & Discussion & 3.58 & .58 & 3.27 & .90 & .01 & .05 & $\mathrm{~S}$ \\
\hline 5 & Problem-solving & 3.51 & .62 & 3.29 & .90 & .01 & .10 & NS \\
\hline 6 & Interview & 3.58 & .62 & 3.28 & .91 & .00 & .03 & $\mathrm{~S}$ \\
\hline 7 & Video clips & 3.64 & .64 & 3.13 & .97 & .00 & .00 & S \\
\hline 8 & Charts & 3.53 & .72 & 3.32 & .91 & .05 & .15 & NS \\
\hline 9 & Projectors & 3.47 & .66 & 3.28 & .89 & .01 & .14 & NS \\
\hline 10 & Lecture & 3.26 & .77 & 3.04 & 1.01 & .07 & .17 & NS \\
\hline 11 & Sociometry & 3.53 & .62 & 3.23 & .94 & .01 & .03 & S \\
\hline 12 & Drilling & 3.40 & .77 & 3.22 & .94 & .12 & .23 & NS \\
\hline 13 & Confrontation & 3.64 & .57 & 3.12 & 1.01 & .00 & .00 & $\mathrm{~S}$ \\
\hline 14 & TV set & 3.53 & .62 & 3.25 & .93 & .01 & .04 & S \\
\hline 15 & Drama & 3.51 & .66 & 3.27 & .93 & .02 & .08 & NS \\
\hline 16 & Brain storming & 3.60 & .68 & 3.32 & .89 & .01 & .03 & $\mathrm{~S}$ \\
\hline 17 & Dramatization & 3.51 & .72 & 3.10 & .97 & .06 & .01 & $\mathrm{~S}$ \\
\hline 18 & Simulation & 3.53 & .66 & 3.18 & 1.01 & .01 & .02 & S \\
\hline 19 & Field trip & 3.60 & .61 & 3.22 & .91 & .01 & .01 & S \\
\hline 20 & Blended learning & 3.58 & .65 & 3.18 & .95 & .02 & .00 & $\mathrm{~S}$ \\
\hline \multirow[t]{2}{*}{21} & Dancing & 3.47 & .75 & 3.25 & .89 & .29 & .15 & NS \\
\hline & Overall mean & & & & & & .07 & NS \\
\hline
\end{tabular}

Table 8 indicated that significant difference was not found in items 1, 2, 5, 8, 9, 10, 12, 15 and 21 with their p-values greater than .05 level of significance. However, there was significant difference in items 3, 4, 6, 7, 11, 13, 14, 16, 17, 18, 19 and 20 with their p-values less than .05 level of significance. The Table further showed that with an overall p-value (.07) greater than .05 level of significance, the hypothesis of no significant difference was hereby not rejected. This implied that there was no significant difference between the mean ratings of facilitators and learners on delivery systems of aesthetic education programme for adults in realization of SDG II in Rivers State.

Table 9. t-test of difference between the mean ratings of facilitators and learners on evaluation strategies of aesthetic education programme for adults in realization of SDG II in Rivers State

\begin{tabular}{|c|c|c|c|c|c|c|c|c|}
\hline \multirow[t]{2}{*}{$\mathbf{S} / \mathbf{N}$} & \multirow[t]{2}{*}{ Item Statements } & \multicolumn{2}{|c|}{$\begin{array}{l}\text { Facilitators } \\
\mathbf{n}=47\end{array}$} & \multicolumn{2}{|c|}{$\begin{array}{l}\text { Learners } \\
\mathrm{n}=489\end{array}$} & \multirow[t]{2}{*}{$\mathbf{t}_{\mathrm{cal}}$} & \multirow[t]{2}{*}{$\mathbf{p}_{\text {value }}$} & \multirow[t]{2}{*}{ Dec } \\
\hline & & $x_{1}$ & $\mathbf{S D}_{1}$ & $x_{2}$ & $\mathbf{S D}_{2}$ & & & \\
\hline 1. & $\begin{array}{c}\text { Using dialogue to ascertain } \\
\text { aesthetic education topics }\end{array}$ & 3.51 & .78 & 3.19 & .92 & .16 & .02 & $\mathrm{~S}$ \\
\hline 2. & $\begin{array}{l}\text { Using video lips to compare art } \\
\text { past and present in the society }\end{array}$ & 3.48 & .75 & 3.37 & .91 & .17 & .48 & NS \\
\hline 3. & $\begin{array}{l}\text { Examining buildings in traditional } \\
\text { and modern architectural styles } \\
\text { using modeling. }\end{array}$ & 3.55 & .65 & 3.21 & .91 & .01 & .01 & $S$ \\
\hline 4. & $\begin{array}{l}\text { Encouraging the creation of works } \\
\text { of art through charts }\end{array}$ & 3.49 & .72 & 3.11 & 1.02 & .02 & .10 & NS \\
\hline 5. & $\begin{array}{l}\text { Developing artistic expression in } \\
\text { various groups through dancing }\end{array}$ & 3.34 & .87 & 3.05 & 1.01 & .16 & .05 & $S$ \\
\hline 6. & $\begin{array}{l}\text { Discussing environmental safety } \\
\text { services through observation }\end{array}$ & 3.64 & .61 & 3.17 & .96 & .00 & .00 & S \\
\hline 7. & $\begin{array}{l}\text { Examining ways of managing } \\
\text { disaster in the environment through } \\
\text { problem solving }\end{array}$ & 3.64 & .61 & 3.26 & .93 & .00 & .01 & $\mathrm{~S}$ \\
\hline & Overall mean & & & & & & .10 & NS \\
\hline
\end{tabular}

Table 9 revealed that items $1,3,5,6$ and 7 with t-calculated values of .16, .01, .16, .00 and .00 had their associated p-values as less than .05 level of significance. Hence, the existence of significant difference on the items. However, items 2 and 4 with t-calculated values of .17 and .02 had their p-values as .48 and .10 greater than .05 level of significance which is an indication of no significant difference on the items. The Table further showed that since an overall p-value (.10) was 
greater than .05 level of significance, the null hypothesis of no significant difference is hereby upheld. This implied that there was no significant difference between the mean ratings of facilitators and learners on evaluation strategies of aesthetic education programme for adults in realization of SDG II in Rivers State.

\subsection{Discussion}

The study found that transmitting knowledge on disaster management and perceptual sensitivity on aesthetic experiences were some of the objectives of aesthetic education programme for adults in realization of sustainable development goal II in Rivers State. These objectives may not have been surprising as respondents observed with dismay the poor environmental condition of Rivers State resulting from exploration and exploitation of petroleum products by multinational oil companies. These activities obviously have pushed millions of vulnerable people into health, social and other dimensions of poverty in the region. Thus, a study by Mottagi and Nowroi (2013) revealed that increased levels of social, health and systematic understanding of social and moral values as one of the importance of aesthetic education. In addition, acquiring aesthetic knowledge will further help the adults in addressing economic losses caused by disasters which is target 11.5 of SDG II. It also goes to show that economic growth could be achieved with aesthetic education providing the kind of learning stimulated by the desire to explore, find out, or search for something (Denaway, 2013). Cuco (2014) further articulated the benefit of this education in terms of leading to a discovery of latent cultural luggage that can compensate for a specific distinctness or spiritual conspicuousness of the person. This view by this author also recognizes the place of safeguarding the cultural norms and values of the people as an objective of aesthetic education in realization of SDG 11 in Rivers State.

The findings further revealed that various contents were contained in aesthetic education programme for adults in realization of sustainable development goal II in Rivers State. Respondents indicated that some of these contents were disaster management, hygiene, environmental safety and environmental beautification. The choice of disaster management may not have been unconnected with the environmental degradation prevalent in the state. Preliminary investigation by researchers with respondents showed that while the inhabitants could not make significant impact on the activities of multinationals in the region, a knowledge on disaster management will help in exposing them to the beautification of their immediate surroundings. This increased aesthetic awareness was supported in a study by Cole (1985).

Addressing other areas for the realization of access to adequate, safe, affordable housing and basic services (target 11.1), and protection and safeguarding of the world's cultural and natural resources (target 11.4) of SDG II, the study by Adu-Agyem and Enti (2009) recommended some activities that could or should be incorporated in the teaching of children to boost creativity. Although, this study was centred on the role of aesthetic education with focus on children, aesthetic however goes beyond expressive arts to awareness and appreciation of natural beauty found in nature and in one's surroundings and linking knowing and feelings to both the cognitive and affective. It is to this end that Acer and Omeroolu (2008) recommended that future aesthetic education programmes and research should include not only children but also teachers and parents. Hence, the acceptance of the null hypothesis as both facilitators and learners shared similar views on what should constitute the contents of aesthetic education in meeting the SDG II in Rivers State.

Findings revealed that several delivery systems were found in aesthetic education programme for adults in realization of SDG II in Rivers State. Some of these delivery systems as revealed by the respondents were observation, brainstorming, modeling, discussion and problem-solving. The wide range of delivery systems depicts the uniqueness of the adults in striving for what will give him/her satisfaction. Kyayankij (2017) in a study on contemplative teaching method to enhance the awareness of aesthetic experience revealed that students mean score of aesthetic awareness and their mean score of aesthetic experience concepts were higher with a statistical significance of .01. This finding may not have been unconnected with the fact that enriching adults aesthetic experience involves making them active with specific roles (Cuco, 2014). A study by Feeney and Moravick (1987) further showed that an interaction and discussion about fine arts is necessary for aesthetic appreciation. This obviously underscores the importance in the use of variety of delivery systems for the achievement of adults' purpose while undergoing any learning activities. It is also not surprising that both the facilitators and learners shared similar ideas on issues relating to the delivery systems following the acceptance of the null hypothesis.

Findings of the study also showed that there were several evaluation strategies of aesthetic education programme for adults in realization of SDG II in Rivers State. Respondents identified problem-solving, observation and modeling as prominent among the strategies. The use of problem-solving as an evaluative strategy may not be unconnected with the fact that adults are in continuous search for improving themselves. Cuco (2014) rightly pointed out that adults are prepared to learn again when faced with life situation for which they need new landmarks. The deplorable condition of Rivers State emanating from oil exploration and exploitation calls for aggressive approach in making the environment habitable. Hence, revitalizing the aesthetic values in the region plays a therapeutic role of maintaining or re-gaining inner 
harmony of re-discovery of the taste of life. The study is further supported by the findings of Mottagi and Nowrozi (2013) that the effectiveness of aesthetic education is evidence in social contexts for learning and problem-solving experience. It is in recognition of this social context that evaluation of works of art and development of artistic expression in various groups in the study was conceived as an evaluation strategy in aesthetic education programme.

The increased in aesthetic awareness of these adults may not have been unconnected with the assertion of Goldsmith and Feldman (1988) that individuals' aesthetic judgement is shaped through processes such as observing, thinking and talking about the subjects, objects and events in the immediate environment. The expression by these authors obviously unravel other evaluative strategies that could be applied in addressing various challenges affecting the individuals within the immediate environment. This also agrees with the view of Acer and Omeroohn (2008) that the development of an individual's critical skills is directly proportionate to their realization of what they see in their immediate surroundings. The curiosity of the adults to improve their immediate surrounding through the acquisition aesthetic knowledge among other things is aimed at achieving target 11.4 of SDG II which has direct impact on the protection and safeguarding of the world's cultural and natural heritage. These prospects were also shared by the facilitators and learners following the acceptance of the null hypothesis as significant difference was not found between their mean scores on evaluation strategies for aesthetic education programme in Rivers State.

\section{Conclusion}

It is believed that while aesthetic education appears to be taught to children, inculcating skills and knowledge on appreciation of beauty through art, exposing the adults with aesthetic values could help in restoring cities by making human settlements inclusive, safe, resilient and sustainable which is SDG II. Agreeably, the objectives of aesthetic education programme vary in locality according to the peculiarity of the people as Acer and Omeroolu (2008) observed that aesthetics is a comprehensive area and that the multiple dimensions of aesthetics education may benefit future studies. One of such studies is the present which is on developing aesthetic education programme for adults in realization of sustainable development goals II in Rivers State. Based on the foregoing, the study concluded that transmitting knowledge for disaster management, promotion of environmental safety services for sustainable communities and development of perceptual sensitivity on aesthetic experiences were some of the objectives of aesthetic education programme. In addition, aesthetic contents in realization of SDG II were disaster management, hygiene (health related issues), environmental beautification and environmental safety.

Furthermore, the application of observation, brainstorming, modeling, discussion and interview were some of the delivery systems of aesthetic education programme, while the integration of problem-solving, the use of video clips, and observation were evaluation strategies. It is in view of these conclusions, that the following recommendations were made.

1. Engaging the adults in identifying additional areas not covered in the present objectives to meet other targets and indicators of SGD II.

2. Intensifying effort to showcase cultural values through cultural fiesta to sustain cultural heritage.

3. Exposing facilitators to further training especially in the area of ICT for effective andragogical practices.

\subsection{Implications for Future Research}

This study was conceived on the notion that adult education is an epicentre of lifelong learning enterprise capable of addressing various challenges through the multiplicity of programmes. It is also believed that a robust aesthetic education programme will accommodate every clientele to acquiring skills for societal transformation. Also, future researchers in aesthetic education programme should include not only the adult learners and facilitators but parents and other vital organs in the society. The present study focused on three targets of SDG II namely 11.1, 11.4 and 11.5 respectively. Similar study may be repeated to accommodate other targets of SDG II.

\section{Acknowledgements}

This study was supported by the Tertiary Education Trust Fund (TETFUND) Institution based research (IBR) grant through the University of Nigeria, Nsukka.

The facilitators who assisted in data collection for the study are acknowledged.

\section{References}

Acer, D., \& Omeroolu, E. (2008). A study on the effect of aesthetic education on the development of aesthetic judgement of six year old children. Early children Educ, 35, 335-342. https://doi.org/10.1007/s10643-007-0193-4

Adu-Agyem, J., \& Enti, M. (2009). Learning: The role of aesthetics in education. Journal of Science of technology, 29(1), 160-168. https://doi.org/10.4314/just.v29i1.46464

Aldrige, A., \& Levine, K. (2001). Surveying the social world: Principles and practice in survey research. Buckingham: 
Open University Press.

Bolajoko, O. A. (2004). Communicable and non-communicable disease. In B.O. Ogundele (Ed), problems in health education, (pp.103-114). Ibadan: Codat Publications Ltd.

Burbarnk, B., \& Pett, D. (2007). Designing printed instructional materials. Onlinelibrary.wiley.com/doi/10./002/pfi50250804.

Burton, D. M. (1994). The arts in school reform: other conservations. Teachers college record, 95, 477-496.

Cole, E. (1985). The effect of a cognitively oriented aesthetic curriculum on the aesthetic judgement and responses of four-, six-and right-year olds enrolled in an art museum program. UMI Proquest Digital Dissertations-Full citation $\&$ Abstract.

Cuco, C. (2014). The role of arts in adult education. Procedia-social and behavioural sciences, 142, $300-305$. https://doi.org/10.1016/j.sbspro.2014.07.692

Denac, O. (2014). The significance and role of aesthetic education. Creative Education, 5, 1714-1719. https://doi.org/10.4236/ce.2014.519190

Denaway, J. (2013). Inquiry based curriculum in a public school art room: Aesthetic education and Lincoln centre institute. Published M.A. Thesis submitted to School of Art, Western Michigan University.

Federal Republic of Nigeria. (2014). National policy on education. Lagos: NERDC.

Feeney, S., \& Moravick, E. (1987). A thing of beauty: Aesthetic development in young children: Young Children, 42(6), $7-15$.

Gall, M. D., Gall, J. P., \& Borg, W. R. (2007). Educational research: An introduction (8 ${ }^{\text {th }}$ edition). Boston: Pearson Educational Inc.

Greener, M. (2001). Variation on a blue guitar: The Lincoln Centre Institute Lecturers on aesthetic education. New York and London: Teachers College Press.

Hogan, C. (2005). Understanding facilitation: Theory and practice. London: Kogan Page Publishers.

Khayankij, S. (2017). Using the contemplative teaching method to enhance the awareness of the aesthetic experience of second-year students majoring in early childhood. Kasetsart Journal of Social Sciences. https://doi.org/10.1016/j.kjss.2017.09.005

Kizlik, R. (2016). Instructional methods. Florida, Boca Raton: Robert Kizlik \& Associates.

Mezirow, J. (1991). Transformative dimensions of adult learning. San Francisco: Jossey-Bass.

Mottagi, Z., \& Nowrozi, R. A. (2013). Aesthetic education requirements and its components in the educational system. Journal of Education and Practice, 4(25), 139-147.

Ogwo, U. (2015). Development of digital resources preservation for effective service delivery in federal university libraries in Nigeria. Unpublished Ph.D Thesis, Department of Library and information science, University of Nigeria, Nsukka.

Olaitan, S. O., \& Ndomi, B. M. (2000). Vocametrics, a high teach-problem solving quantitative text with computation skills. Onitsha: Cape publishers international Ltd.

Olori, C. N. (2019). Adult education and illiteracy eradication. In A.N. Ugwu \& O.F. Mbalisi (Ed), Contemporary issues in adult education: An African perspective. (pp. 109-117). Port-Harcourt: Pearl Publishers Internationals Ltd.

Osinem, E. C. (2008). Managing agricultural education and training resources: principles and methods. Enugu: Belony Publishers.

Reimer, B. (1998). Volume IV: What knowledge is of most worth in the arts? Philosophy of education. Mayor themes in the analytic tradition. In P.H-Hirst \& P. White (Eds), Problems of educational content and practices. London, New York: Routledge.

Ruiz, J. (2004). A literature review of the evidence base for culture, the arts and sport policy. Edinburgh: Scottish Executive Education Department.

Sule, M. N. (2004). Sociology of education in perspective. Jos: Deka publishers.

Ugbomeh, B. A. (2008). Critical issues in the Niger Delta region which way out? Conference proceedings on the Nigerian state, oil industry and the Niger Delta, 863-868.

UNESCO. (2003). Artistic practices and techniques form Europe and North America favouring social cohesion and 
peace. Paris, UNESCO.

United Nations. (2015). Transforming our world: The 2030 agenda for sustainable development.

\section{Copyrights}

Copyright for this article is retained by the author(s), with first publication rights granted to the journal.

This is an open-access article distributed under the terms and conditions of the Creative Commons Attribution license (http://creativecommons.org/licenses/by/4.0/). 